REVISTA DE DERECHO UNED, NÚM. 28, 2021

\title{
EL RESPETO A LA DIGNIDAD HUMANA DE LAS PERSONAS PRIVADAS DE LA LIBERTAD CONFORME A LA JURISPRUDENCIA DE LA CORTE INTERAMERICANA DE DERECHO HUMANOS
}

\author{
RESPECT FOR THE HUMAN DIGNITY OF PERSONS DEPRIVED \\ OF LIBERTY IN ACCORDANCE WITH THE CASE LAW OF THE \\ INTER-AMERICAN COURT OF HUMAN RIGHTS
}

\author{
Carla Irene Furingo ${ }^{1}(*)$ \\ Universidad Católica Argentina
}

Sumario: I. Introducción; II. Vulnerabilidad y respeto de la dignidad humana de las personas privadas de la libertad; III. Noción de tortura y otros tratos o penas crueles inhumanos o degradantes en la normativa internacional; IV. Cuestiones jurídicas. IV.1. Concepto de Tortura conforme a la jurisprudencia de la Corte Interamericana de Derechos Humanos. IV.1.A. Concepto de Tratos o penas crueles, inhumanos y degradantes conforme a la jurisprudencia de la Corte Interamericana de Derechos Humanos. IV.2. La prohibición absoluta de la tortura y su pertenencia al dominio del ius cogens internacional en la jurisprudencia de la Corte Interamericana de Derechos

\footnotetext{
1 * Doctoranda en Ciencias Jurídicas Universidad Católica (Buenos Aires, Argentina). Graduada de abogada en la Universidad Nacional de Lomas de Zamora, profesora adjunta en la Universidad Nacional de Lomas de Zamora, catedra instrumento del derecho Comercial, integrante del proyecto de investigación PICTO 20170032 de la Universidad Católica Argentina, integrante del proyecto de investigación del Centro de estudios judiciales de la Universidad Nacional de Lomas de Zamora. Agente fiscal en la provincia de Buenos Aires Argentina, correo carla.furingo@ yahoo.com.ar.
} 
Humanos. IV.2.A. Planteamiento general. IV.2.B. Tortura; IV.2.C. Tratos Crueles Inhumanos o Degradantes. V. Deberes y obligaciones del estado ante casos de tortura y otros tratos o penas crueles, inhumanos y degradantes padecidos por personas privadas de la libertad. V.2. Deber de prevención; V.3. Deber de sancionar, cumplir las leyes y excluir las pruebas obtenidas mediante tortura. VI. Conclusión; VII. Bibliografía. VII.1. Jurisprudencia de la Corte Interamericana de Derechos Humanos.

Resumen: El objetivo de este artículo es analizar el respeto de la dignidad humana de las personas privadas de la libertad y la determinación del alcance de la prohibición internacional de tortura y otros tratos o penas crueles inhumanos o degradantes. El trabajo jurisprudencial de los tribunales internacionales de derechos humanos ha contribuido a definir las nociones de tortura o tratos crueles y ha fortalecido el carácter absoluto de la prohibición. Ha jugado en ello un rol fundamental el carácter progresivo del derecho internacional de los derechos humanos. El presente trabajo sistematiza los criterios jurisprudenciales aplicados por la Corte IDH en el periodo de los años 1989 y 2021 para delimitar el alcance de la prohibición de la tortura y los otros tratos.

Palabras claves: Respeto Dignidad Humana personas privada libertad.

Abstract: The objective of this article is to analyze respect for the human dignity of persons deprived of liberty and to determine the scope of the international prohibition of torture and other cruel, inhuman or degrading treatment or punishment. The jurisprudential work of international human rights tribunals has contributed to defining the notions of, torture or cruel treatment and has strengthened the absolute nature of the prohibition. The progressive character of international human rights law has played a fundamental role in this. This work systematizes the jurisprudential criteria applied by the Inter-American Court in the period between 1989 and 2021 to define the scope of the prohibition of torture and other treatment.

Keywords: Respect for the human dignity of persons deprives of liberty international prohibition of torture or inhuman and degrading, analyses the opinion of the Interamerican Human Rights Court.

Recepción original: 12-04-2021

Aceptación original: 17-09-2021 


\section{INTRODUCCIÓN}

La integridad personal y el respeto a la dignidad humana de las personas privadas de la libertad es hoy uno de los derechos humanos sobre el que se ejerce más presión en el mundo. Lo han denunciado los recientes informes de organizaciones internacionales como Amnistía Internacional ${ }^{2}$, y el Comité de Expertos de Naciones Unidas Contra la Tortura ${ }^{3}$. En el derecho internacional de derechos humanos la tortura y los tratos o penas crueles, inhumanos y degradantes están absolutamente prohibidos.

La prohibición de tortura y los tratos crueles, inhumanos o degradantes se ha desarrollado en múltiples instrumentos internacionales apreciándose en ellos a la vez importantes avances. No obstante, también, existen debilidades estratégicas vinculadas con la complejidad del control jurisdiccional internacional, ya que la base de la competencia de los tribunales internacionales está sujeta a la voluntad de los estados.

En las últimas cinco décadas la Corte IDH ha resuelto más 40 casos en los cuales la vulneración de los derechos había recaído en víctimas privadas de la libertad, en el interior de una prisión o lugar de detención.

De acuerdo con la jurisprudencia de la Corte IDH los derechos vulnerados de la Convención de derechos humanos con mayor frecuencia en el interior de los recintos de detención son: el derecho a la vida (artículo 4), derecho a la integridad corporal (artículo 5), la prohibición de esclavitud y servidumbre (artículo 6), garantías judiciales (artículo 8), libertad de conciencia y religión(artículo), el principio de legalidad y retroactividad(artículo 9), el derecho a la protección de la familia (artículo 17).

Los países que han sido condenados por la Corte IDH por vulnerar los derechos en el interior de las prisiones son: Perú con 12 condenas, Argentina 6 condenas Ecuador, Venezuela con 5 condenas, Honduras con 4 condenas, otros países como Haití, Trinidad, Tobago, Brasil habían sido condenados en 2 ocasiones, mientras que

2 ONG, Informe de Amnistía internacional (Londres)Reino Unido, fecha 2018. Disponible en <Universidad Católica Argentina web.pdf>. [consultado el 13/11/2020].

3 ONU, Informe del Comité de Expertos de Naciones Unidas contra la Tortura, (New York) 2020. Disponible en <Respeto Dignidad Humana personas privada libertad://www.ohchr.org/SP/HRBodies/cat/page/CATIndex.aspx.> [consultado el 13/11/2020]. 
México, Guatemala, Barbados, Colombia, Paraguay Bolivia y Suriman han sido condenados en una sola ocasión. ${ }^{4}$

En este trabajo analizaremos los criterios elaborados por la Corte IDH para la delimitación de que significa el respeto a la dignidad humana de las personas privadas de la libertad y la determinación del alcance de la prohibición de tortura u otros tratos crueles Inhumanos y degradantes. Antes de iniciar el examen del alcance de la prohibición en la jurisprudencia de la Corte IDH, indagaremos brevemente el concepto de tortura y los otros tratos crueles inhumanos, y su pertenencia al dominio del ius cogens internacional.

\section{VULNERABILIDAD Y RESPETO DE LA DIGNIDAD HUMANA DE LAS PERSONAS PRIVADAS DE LA LIBERTAD}

La normativa internacional en materia de derechos humanos considera que los sujetos privados de la libertad por parte del estado, pertenecen al grupo de personas vulnerables. La vulnerabilidad se debe a la total dependencia que tienen los penados con la institución penitenciaria, es decir ellos no pueden satisfacer sus necesidades de manera independiente y son sometidos a rutinas o regímenes de vida con diferentes niveles de rigidez y esto hace que sea vea disminuida su autonomía 5 .

Como señalan Bellof y Clerico $^{6}$, «Todo individuo tiene derecho a condiciones de existencia digna surge como contenido del derecho a la vida y a la integridad física. Se considera que este derecho se viola también por omisión estatal, más precisamente, por incumplimiento de obligaciones positivas del Estado para generar condiciones que garanticen una vida digna, ya sea de niños, de personas detenidas o internadas, de comunidades indígenas o de otros grupos en situación de vulnerabilidad».

Por ello las personas privadas de la libertad, cuentan con garantías y mecanismos de protección contemplados en los distintos tratados

4 World Prison brief data: América del Sur, sitio web Centro internacional de estudios penitenciarios, disponible en $<$ http || bit.ly|2SgNbS7 $>$ [Consultado en fecha 20/11/2020].

5 NASH ROJAS, C, Personas privadas de la libertad y medidas disciplinarias en Chile. Análisis y perspectiva desde los derechos humanos, 1. ${ }^{a}$ ed. Santiago de Chile, (Editorial Andros Impresores), 2013, pp. 20-23.

6 BELLOF, M y CLERICO, L "Derecho a condiciones de existencia digna y situación de vulnerabilidad en la jurisprudencia de la Corte Interamericana», Estudios constitucionales, 14, 2016, pp 139-178 disponible en <https://scielo.conicyt.cl/pdf/ estconst/v14n1/art05.pdf>. [consultado el 23/05/2020]. 
internacionales de derechos humanos cuyo objetivo es resguardar los derechos a la vida, dignidad e integridad física y psíquica.

Los estándares de la Corte IDH, contemplan que las personas privadas de la libertad por parte del estado, se encuentran en una relación de sujeción especial, que lo sitúa en una situación de vulnerabilidad, que obliga a los estados a brindarle protección hasta el punto de convertirse en garante.

Debemos recordar que durante mucho tiempo el paradigma fue muy distinto. La teoría de las relaciones de especial sujeción ${ }^{7}$, surge en la época de la monarquía constitucional alemana a lo largo del siglo XIX, la construcción normativa es obra de Paul Laband y Jellinek, y su sistematización dentro de la teoría de la ciencia administrativa — se le atribuye a Otto Mayer - Esta teoría estaba conformada por una estructura dualista se diferenciaba entre; las relaciones estadociudadano, o sea las relaciones del estado con el exterior, y las relaciones estado-servidores es decir las internas.

Dentro de esta última esfera - las internas - es donde surgen las relaciones de especial sujeción, según las cuales determinadas personas-presos, funcionarios, militares y estudiantes - que mantienen una relación jurídica con la administración tendrían un estatus especial caracterizado por una dependencia intensificada con la administración basándose en la cual esta tiene una capacidad prácticamente ilimitada para alcanzar sus objetivos.

Desde tales presupuestos, tal teoría presenta tres problemas principales; la validez del principio de legalidad, la validez de los derechos fundamentales y la protección de los derechos fundamentales. Llevándonos a la conclusión de que desde tal postura los derechos fundamentales, así como la Reserva de Ley no tendrían ninguna validez dentro de la mencionada teoría. En consecuencia F. Tezner${ }^{8}$ llegó a afirmar «que las relaciones de especial sujeción representaban un bastión del Estado absoluto en el contexto de un Estado constitucional».

Por lo tanto, el estatuto jurídico de los presos quedaba reducido a una forma sencilla en la que solo eran titulares de obligaciones, y

7 GALLEGO ANABITARTE, A, "Las relaciones de especial sujeción y el principio de legalidad de la Administración» en Revista de Derecho Público, n. ${ }^{\circ}$ 34, 1961, pp. 11 y ss.

GARCÍA MACHO, R., «En torno a las garantías de los Derechos fundamentales en el ámbito de las relaciones de especial sujeción», Revista de Estudios de Derecho Administrativo, Madrid, 1989, menciona a F. TEZNER, «Das freie Ermessen der Verwaltungsbehörden», 1924. 
donde la regulación penitenciaria se limitaba a órdenes de servicio o disposiciones dirigidas a resolver cuestiones muy específicas. ${ }^{9}$

Con la entrada en vigor de la Ley Fundamental en Alemania, se consagra la validez de los derechos fundamentales en la esfera de los estatus especiales ${ }^{10}$. Eso significaba que una limitación sobre cualquier derecho fundamental solamente sería válida si está reconocida al máximo nivel constitucional.

En este sentido la sentencia Bundesverfassungsgericht del Tribunal Constitucional Alemán ${ }^{11}$ del 14 de marzo de 1972, expresamente manifiesto que los derechos fundamentales de los presos, solo podían restringirse sobre la base de una Ley. Con esta resolución del Alto Tribunal Alemán, se deja a un lado la teoría de las relaciones de sujeción especial para declarar que no sería constitucional una limitación de derechos fundamentales de la persona con base en una norma de rango administrativo.

La protección de los derechos fundamentales de las personas privadas de libertad y la posición de garante del estado, fue ampliamente desarrollado por el sistema internacional de los derechos humanos y los estándares de la jurisprudencia del Tribunal Europeo de Derechos Humanos y de la Corte IDH, los cuales modificaron esta lógica, otorgándole una nueva dimensión a la noción de relación de sujeción especial. Este cambio no ocurrió para conceder espacios de discrecionalidad y posibilidad de extralimitaciones por parte de la administración pública, sino para incorporar un lenguaje de derechos del condenado, de límites y resguardos que deben desarrollarse para contener de forma razonable los riesgos que se materializan en la prisión, como muertes, enfermedades, peleas, abusos de funcionarios provocando torturas $\mathrm{u}$ otros tratos crueles o degradantes, motines y huelgas de hambre.

Analizando la jurisprudencia de la Corte IDH, en materia de privados de la libertad, es necesario destacar que el estándar general

9 ALAVARO CASTRO CICLERO M y MERA, J, Derechos fundamentales de las personas privadas de la libertad, Chile, (Ediciones universidad Diego Portales), 2010, pp.29.

10 Ley Fundamental de la República de Alemania (Ley Fundamental de Bonn) de 1949. Art. $1^{\circ}-3$ que vincula a todos los poderes públicos, también el ejecutivo.

11 RIVERA BEIRAS, I., (2000) "La doctrina de las relaciones de sujeción especial en el ámbito penitenciario (la zona del no derecho)", Legalidad constitucional y relaciones penitenciarias de especial sujeción, Bosch, Barcelona; MAPELLI CAFFARENA, B., (1993) "Las relaciones especiales de sujeción y el sistema penitenciario", Estudios Penales y Criminológicos (XVI), Santiago de Compostela. 
que se establece en esta temática es la protección a la dignidad humana como limite a la fuerza del estado.

Si bien es un deber del estado dictar leyes penales efectivas para disuadir la comisión de delitos contra las personas e implementar un sistema dirigido a la prevención y castigo de conductas que transgredan las normas, para de esta manera garantizar el orden público, y los derechos de los ciudadanos ${ }^{12}$.

El mismo en cumplimiento de su deber debe garantizar la seguridad de sus habitantes, pero no puede valerse de cualquier procedimiento arbitrario o abusivo para alcanzar sus objetivos, es decir adoptar una política criminal sin límites, arbitraria por parte de los operadores del estado, provocando violación de los derechos humanos y un desprecio a la dignidad humana.

Del plexo jurisprudencial emitido por la Corte IDH, en especial ha sido enfática en la sentencia en el caso Montero Aranguren ${ }^{13}$ al establecer que el estado debe ocupar la posición de garante de las personas privadas de la libertad, tiene la obligación de custodia y protección de los mismos, es decir es responsable de desplegar medidas que aseguren el orden dentro de la unidad carcelaria y de garantizar que a los internos se le respete sus condiciones compatibles con la dignidad humana.

\section{NOCIÓN DE TORTURA Y OTROS TRATOS O PENAS CRUELES INHUMANOS O DEGRADANTES EN LA NORMATIVA INTERNACIONAL}

La regulación normativa de tortura u tratos crueles inhumanos o degradantes en el ámbito internacional se dirige fundamentalmente a instituir su prohibición absoluta. La noción de tortura es abordada exclusivamente por la Declaración y Convención Contra la Tortura y Otros Tratos o Penas Crueles Inhumanos o Degradantes de Naciones

12 La prohibición de tortura y los tratos crueles, inhumanos o degradantes se ha desarrollado en múltiples instrumentos internacionales apreciándose en ellos a la vez importantes avances. No obstante, también, existen debilidades estratégicas vinculadas con la complejidad del control jurisdiccional internacional, ya que la base de la competencia de los tribunales internacionales está sujeta a la voluntad de los estados. En las últimas cinco décadas la Corte IDH ha resuelto más 40 casos en los cuales la vulneración de los derechos había recaído en víctimas privadas de la libertad, en el interior de una prisión o lugar de detención.

${ }_{13}$ Cfr. Corte IDH caso Montero Aranguren y otros (Retén de Catia) VS. Venezuela. Excepción preliminar y de fondo y reparaciones y costas. Sentencia de 5 de julio de 2006 serie C número 150. 
Unidas y por la Convención Interamericana para Prevenir y Sancionar la Tortura.

La prohibición de la tortura $\mathrm{u}$ otros tratos crueles inhumanos o degradantes fue reconocida en 1948 en la Declaración Universal de Derechos Humanos ${ }^{14}$ en su (artículo 5), si bien no se define en el artículo que se entiende por tortura o tratos Crueles inhumanos o degradantes si los menciona y los prohíbe, posteriormente fue incluida en numerosos tratados internacionales.

La Declaración sobre la Protección de todas las Personas contra la Tortura y Otros Tratos o Penas Crueles Inhumanos o Degradantes $^{15}$, fue de gran importancia porque por primera vez en un tratado internacional, se define y se diferencia a la tortura y tratos crueles inhumanos o degradantes.

Siguiendo esta orden de ideas Carlos Garduño Salinas ${ }^{16}$, establece que «La inflicción a la víctima o a un tercero de dolores o sufrimientos graves físicos o psíquicos cometida por un funcionario tiene como finalidad obtener información, conseguir una confesión, castigar por un hecho que se haya cometido o se sospeche que se cometió, intimidar».

14 ONU, Declaración Universal de Derechos Humanos. Adoptada y proclamada por la Asamblea General de la ONU en Resolución 217 A (III), el 10 de diciembre de 1948 Artículo 5. Nadie será sometido a torturas o ni a penas o tratos crueles, inhumanos o degradantes. Disponible en: <http://www.un.org/es/documents /udhr/ >. [consultado el 23/05/2020].

15 ONU, Declaración sobre la Protección de Todas las Personas contra la Tortura y Otros Tratos o Penas Crueles Inhumanos o Degradantes. Adoptada por la Asamblea General en su resolución 3452 el 9 de diciembre de 1975, Artículo 1. 1. A los efectos de la presente Declaración, se entenderá por tortura todo acto por el cual un funcionario público, u otra persona a instigación suya, inflija intencionalmente a una persona penas o sufrimientos graves, ya sean físicos o mentales, con el fin de obtener de ella o de una tercera información o una confesión, de castigarla por un acto que haya cometido o se sospeche que ha cometido, o de intimidar a esa persona o a otras. No se considerarán torturas las penas o sufrimientos que sean consecuencia únicamente de la privación legítima de la libertad, o sean inherentes o incidentales a esta, en la medida en que estén en consonancia con las Reglas Mínimas para el Tratamiento de Reclusos. 2. La tortura constituye una forma agravada y deliberada de trato o pena cruel, inhumano o degradante. Disponible en $<$ http//daccesddsny. un.org/doc/RESOLUTION/GEN/NRO/783/65/PDF/NRO78365.pdf? OpenElement>. [consultado el 23/05/2020].

16 GARDUÑOS SALINAS, C," La finalidad de la Tortura en el derecho internacional Mexicano de Derechos Humanos, Consideraciones para la investigación y documentación de la Tortura en México ", 1 ed. México, (Oficina en México del Alto Comisionado de Naciones Unidas para los Derechos Humanos), 2007, pp 155. 
Por su parte, la Convención contra la Tortura y Otros Tratos o Penas Crueles Inhumanos o Degradantes ${ }^{17}$, resulta ser el tratado principal de la ONU dedicado únicamente a prohibir, prevenir y combatir la tortura. Este es el primer instrumento internacional en el cual los estados partes se comprometen a tipificar los actos de tortura como delitos en su legislación penal y a castigar los mismos con penas adecuadas. La convención cuenta con tres partes, en la parte I se define en el artículo 2 que se entiende por tortura, dolores o sufrimientos graves ya sean físicos o mentales no especifica que se entiende por tratos o penas crueles, inhumanos o degradantes. Al respecto O Donnell ${ }^{18}$, ha señalado «Que se ha hecho referencia a los tratos o penas crueles, inhumanos o degradantes cuando hay sufrimiento psicológico o moral, que no incluya abuso físico, lo que estima que si incluye padecimiento psicológico o moral y físico es tortura».

Asimismo la Convención Interamericana para Prevenir y Sancionar la Tortura $^{19}$, es un instrumento Internacional creado dentro de

17 ONU, Convención contra la Tortura y Otros Tratos o Penas Crueles Inhumanos o Degradantes, Adoptada y abierta a la firma, ratificación y adhesión por la Asamblea General de Naciones Unidas el 10 de diciembre de 1984, Artículo 1. 1. A los afectos de la presente Convención, se entenderá por el término "tortura" todo acto por el cual se inflijan intencionalmente a una persona dolores o sufrimientos graves, ya sean físicos o mentales, con el fin de obtener de ella o de un tercero información o una confesión, de castigarla por un acto que haya cometido, o se sospeche que ha cometido, o de intimidar o coaccionar a esa persona o a otras, o por cualquier razón basada en cualquier tipo de discriminación, cuando dichos dolores o sufrimientos sean infligidos por un funcionario público u otra persona en el ejercicio de funciones públicas, a instigación suya, o con su consentimiento o aquiescencia. No se considerarán tortura los dolores o sufrimientos que sean consecuencia únicamente de sanciones legítimas, o que sean inherentes o incidentales a estas. Disponible en <http://www2.ohchr.org/spanih/law/cat.htm >. [consultado el 23/11/2020].

18 O DONNELL, D, La Tortura y trato cruel inhumano y degradante, contenido y significado en el derecho Internacional de los Derechos Humanos, Instrumentos Nacionales E internacionales para prevenir, investigar y sancionar la tortura. Secretaria de Relaciones Exteriores, Programa de Cooperación sobre Derechos Humanos, Comisión Europea, México,2005, pp 99.

19 OEA, La Convención Interamericana para Prevenir y Sancionar la Tortura. Promulgada el 9 de diciembre de 1985 entro en vigencia 28 de febrero de 1987, dentro de las organizaciones de los estados americanos (OEA) Artículo 2. Para los efectos de la presente Convención se entenderá por tortura todo acto realizado intencionalmente por el cual se inflijan a una persona penas o sufrimientos físicos o mentales, con fines de investigación criminal, como medio intimidatorio, como castigo personal, como medida preventiva, como pena o con cualquier otro fin. Se entenderá también como tortura la aplicación sobre una persona de métodos tendientes a anular la personalidad de la víctima o a disminuir su capacidad física o mental, aunque no causen dolor físico o angustia psíquica. No estarán comprendidos en el concepto de tortura las penas o sufrimientos físicos o mentales que 
las Organizaciones de los Estados Americanos (OEA), con el objetivo de prevenir y sancionar casos de tortura o tratos crueles inhumanos o degradantes, en el artículo 2 define que se entiende por tortura y tratos crueles inhumanos y degradantes de una manera más amplia, que la Convención Contra la Tortura y otros Tratos Crueles Inhumanos y Degradantes de Naciones Unidas, incluyendo como tortura o tratos crueles inhumanos o degradantes "el uso de métodos sobre una persona con la intención de anular la personalidad de la víctima o disminuir su capacidad física o mental, incluso si no causa dolor físico o angustia psicológica".

El lenguaje de la Convención Interamericana para Prevenir y Sancionar la Tortura es más restrictivo que el de la Convención Americana porque se refiere únicamente a la tortura. Sin embargo, la Corte IDH ha indicado que la prohibición de la tortura y otros tratos crueles o penas crueles inhumanos o degradantes no admiten derogación ${ }^{20}$.

Por otro lado, el Convenio Europeo para la prevención de la Tortura y de las penas o tratos crueles ${ }^{21}$, es un instrumento internacional que no contiene normas encaminadas para la prohibición de estas conductas. En su Artículo 1 se crea un comité europeo para la prevención de la tortura, el cual está conformado por órganos de expertos que hacen visitas periódicas a lugares donde hay personas privadas de la libertad examinando el trato que se les da.

sean únicamente consecuencia de medidas legales inherentes a estas, siempre que no incluyan la realización de los actos o la aplicación de los métodos a que se refiere el presente artículo. Disponible en <http///www.defensoria.org.ar/wp-content/ uploads2017/02/conevencionInteramericanaContraTortura.pdf. > [consultado el 23/11/2020].

20 Cfr. Corte IDH caso Caesar Vs. Trinidad y Tobago, es un instrumento internacional que no contiene normas encaminadas para la prohibición de estas conductas, en su artículo 1 se crea un comité Europeo para la prevención de la tortura, el cual está conformado por órganos de expertos que hacen visitas periódicas a lugares donde hay personas privadas de la libertad examinando el trato que se les da, para reforzar llegado el caso su protección contra tortura u tratos crueles inhumanos y degradantes.-.

${ }_{21}$ Consejo de Europa, Convenio Europeo para la Prevención de la Tortura y de las Penas o Tratos Crueles Inhumanos y Degradantes, celebrado en Estrasburgo el 26 de noviembre de 1987 entro en vigencia el 1 de febrero de 1989, artículo 1 Se crea un Comité Europeo para la Prevención de la Tortura y de las Penas o Tratos Inhumanos o Degradantes (denominado a continuación: «el Comité»). Por medio de visitas, este Comité examinará el trato dado a las personas privadas de libertad para reforzar, llegado el caso, su protección contra la tortura y las penas o tratos inhumanos o degradantes. Disponible en < https://dhpedia.wikis.cc/wiki/Convenio_ Europeo_para_la_Prevenci\%C3\%B3n_de_la_Tortura_y_de_las_Penas_o_Tratos_ Inhumanos_o_Degradantes $>$ [Consultado 01/12/2020] 
De los textos internacionales analizados, tanto la Declaración Universal de los Derechos Humanos, el Artículo 3 común de los Convenios de Ginebra, como el Pacto sobre Derechos Civiles y Políticos ${ }^{22}$ y el $\mathrm{CEDH}^{23}$, establecen la imposibilidad de suspender, ni aun en caso de guerra u otros supuestos de igual gravedad, la garantía al derecho a la integridad personal.

En esta orden de ideas, Carrillo Salcedo ${ }^{24}$, ha sostenido "Que una de las más importantes contribuciones del CEDH es que junto con el artículo 3, común de los Convenios de Ginebra, ha contribuido a establecer un núcleo duro, de los derechos humanos, inderogables aun las situaciones más graves como la guerra. Entre estos derechos se encuentra la prohibición de la tortura y los tratos crueles, inhumanos y degradantes. El problema se plantea a partir de la interpretación de la Convención Contra la Tortura ${ }^{25}$ y la Convención Interamericana para Prevenir y Sancionar la Tortura ${ }^{26}$. En

22 ONU, Asimismo las Reglas Minimas de Naciones Unidas para el Tratamiento de los Reclusos (Reglas Nelson Mándela), fueron de gran importancia en el derecho internacional porque establecen reglas de cómo se deben tratar a las personas privadas de la libertad, en los establecimientos penitenciarios, en su regla 1 establece que todos los reclusos deben ser tratados con el respeto que merece su dignidad humana, prohíbe que sean sometidos a torturas $\mathrm{u}$ a otros tratos crueles inhumanos o degradantes, y no podrá invocarse ninguna circunstancia como justificación en contrario.

23 Convención Europea de Derechos Humanos. 1 de junio de 2010. Artículo 15. Derogación en caso de urgencia. 1. En caso de guerra o de otro peligro público que amenace la vida de la nación, cualquier Alta Parte Contratante podrá tomar medidas que deroguen las obligaciones previstas en el presente Convenio en la medida estricta que lo exija la situación, y supuesto que tales medidas no estén en contradicción con las otras obligaciones que dimanan del derecho internacional. 2. La disposición precedente no autoriza ninguna derogación al artículo 2 , salvo para caso de muertes resultantes de actos ilícitos de guerra, y a los artículos 3 (Prohibición de la Tortura), 4 (Párrafo 1) y 7. <Disponible en La garantía de la integridad personal es una clara y unívoca estigmatización como delito de "tortura", adecuadamente castigado, de cualquier forma, de dolor o sufrimiento indebidamente infligidos por funcionarios públicos a ciudadanos privados de su libertad

24 CARRILLO SALCEDO, J En esta orden de ideas Zaffaroni, señala que «La tortura es la producción de dolor físico para la obtención de información, y en ocasiones tiene por objetivo la destrucción de la autoconciencia y de la autoestima».

25 ONU, Convención Contra la Tortura y Otros Tratos o Penas Crueles Inhumanos o Degradantes. Artículo 2. 1. Todo Estado parte tomará medidas legislativas, administrativas, judiciales o de otra índole eficaces para impedir los actos de tortura en todo territorio que esté bajo su jurisdicción. 2. En ningún caso podrán invocarse circunstancias excepcionales tales como estado de guerra o amenazas de guerra, inestabilidad política interna o cualquier emergencia pública como justificación de la tortura. 3. No podrá invocarse una orden de un funcionario superior o de una autoridad pública como justificación de la tortura. <http://www2.ohchr.org/spanih/ law/cat.htm > [consultado el 13/11/2020].

26 OEA, Convención Americana para Prevenir y Sancionar la Tortura. Artículo 4. El hecho de haber actuado bajo órdenes superiores no eximirá de la responsabi-

(c) UNED. Revista de Derecho UNED, núm. 28, 2021 
ambos textos se prohíbe expresamente la utilización de la tortura, aun en las situaciones más graves, pero no hacen referencia a los otros tratos crueles.

Asimismo, las Reglas Mínimas de Naciones Unidas para el Tratamiento de los Reclusos (Reglas Nelson Mándela) ${ }^{27}$, fueron de gran importancia en el derecho internacional porque establecen reglas de cómo se deben tratar a las personas privadas de la libertad, en los establecimientos penitenciarios. En su regla 1 establece que todos los reclusos deben ser tratados con el respeto que merece su dignidad humana, prohíbe que sean sometidos a torturas $\mathrm{u}$ a otros tratos crueles inhumanos o degradantes, y no podrá invocarse ninguna circunstancia como justificación en contrario.

\section{CUESTIONES JURÍDICAS}

El respeto a la dignidad Humana y la prohibición absoluta que funcionarios públicos infrinjan actos de tortura o tratos crueles inhumanos y degradantes a las personas privadas de la libertad, ha sido ampliamente desarrollado por la doctrina y por la jurisprudencia de los Tribunales internacionales.

Por su parte Ferrajoli ${ }^{28}$, establece que «La garantía de la integridad personal es una clara y unívoca estigmatización como delito de "tortura", adecuadamente castigado, de cualquier forma, de dolor o sufrimiento indebidamente infligidos por funcionarios públicos a ciudadanos privados de su libertad».

lidad penal correspondiente. Artículo 5. No se invocará ni admitirá como justificación del delito de tortura la existencia de circunstancias tales como estado de guerra, amenazas de guerra, estado de sitio o de emergencia, conmoción o conflicto interior, suspensión de garantías constitucionales, la inestabilidad política interna $\mathrm{u}$ otras emergencias o calamidades públicas. $<\mathrm{http} / /$ www.defensoria.org.ar/wp-content/uploads2017/02/conevencionInteramericanaContraTortura.pdf. > [consultado el 13/11/2020].

27 Reglas Mínimas de Naciones Unidas para el Tratamiento de los Reclusos Nelson Mándela, celebrada en Viena del 18 al 22 de mayo de 2015, regla 1 Todos los reclusos serán tratados con el respeto que merecen su dignidad y valor intrínsecos en cuanto seres humanos. Ningún recluso será sometido a tortura ni a otros tratos o penas crueles, inhumanos o degradantes, contra los cuales se habrá de proteger a todos los reclusos, y no podrá invocarse ninguna circunstancia como justificación en contrario. Se velará en todo momento por la seguridad de los reclusos, el personal, los proveedores de servicios y los visitantes.

28 FERRAJOLI, L «Las libertades en el tiempo del Neoliberalismo» Isonomía Revista de teoría o filosofía del derecho n. 29 (2008) pp 1-15 [consultado el 23/11/2020]. 
Es conteste la doctrina al establecer que se consideran actos de tortura u tratos crueles inhumanos y degradantes, no solo los que causan un sufrimiento físico sino también aquellos que provocan un padecimiento mental, a las personas privadas de la libertad.

En esta orden de ideas Zaffaroni ${ }^{29}$, señala que «La tortura es la producción de dolor físico para la obtención de información, y en ocasiones tiene por objetivo la destrucción de la autoconciencia y de la autoestima».

El delito de tortura u otros tratos crueles infligidos a las personas privadas de la libertad afecta no solo la integridad física y psíquica sino también la dignidad humana, de aquellos que lo padecen.

Por su parte Foucault ${ }^{30}$, señala que la Tortura ha sido considerada como un acto que agravia a la humanidad, es uno de los delitos que destruye lo más preciado de la persona, su integridad humana. De ahí que, en diversas legislaciones, internacionales se ha considerado incluso como un crimen de lesa humanidad.

En este apartado centraremos nuestro interés en primer lugar en analizar el concepto de tortura y tratos crueles inhumanos o degradantes conforme a la jurisprudencia de la Corte IDH, y en segundo lugar abordaremos la prohibición absoluta de tormentos y su pertenencia al dominio del ius cogens internacional.

\section{IV.1. Concepto de Tortura conforme a la jurisprudencia de la Corte Interamericana de Derechos Humanos}

De acuerdo con la jurisprudencia de la Corte IDH, la tortura se constituye por un acto: (1) que sea intencional, es decir que los actos cometidos no sean producto de una conducta imprudente, accidental o de un caso fortuito; (2) que cause severos sufrimientos físicos o mentales, lo cual se determina al considerar factores endógenos y exógenos, tales como las características del trato, la duración, el método utilizado o el modo en que fueron infligidos los padecimientos, los efectos físicos y mentales que estos tienden a causar (factores endógenos), así como las condiciones particulares de la persona que sufre dichos padecimientos, como es la edad, el sexo, el estado

29 ZAFFARONI, R «La filosofía del sistema Penitenciario en el mundo contemporáneo». Revista de derecho Penal Themis n. ${ }^{\circ}$ 35, Perú, 1997, pp 179-191 disponible en $<$ https://dialnet.unirioja.es/servlet/articulo?codigo $=5109535>$ [consultado el 23/11/2020].

30 FOUCAULT, M. Vigilar y Castigar. España (Siglo XXI Editores). 1996. 
de salud y cualquier otra circunstancia personal (factores exógenos), (3)que se cometa con cualquier fin o propósito, como podría ser forzar una confesión en el sentido deseado por las autoridades ${ }^{31}$.

Para conceptualizar adecuadamente los diferentes elementos que componen el sufrimiento mental que es constitutivo de tortura, la Corte IDH ha creado el concepto de tortura psicológica. En el cual se establece, que todo tormento mental es producido cuando exista amenazas y el peligro real de someter a una persona a lesiones físicas, y que estas circunstancias le generen una angustia moral de grado tal que pueden ser calificadas de esta manera ${ }^{32}$. En el caso Cantoral Benavides $v$. Perú ${ }^{33}$, se estableció que debe calificarse como torturas psíquicas aquellos actos de agresión infligidos a una persona que han sido preparados y realizados deliberadamente contra la víctima para suprimir su resistencia psíquica y forzarla a auto inculparse o a confesar determinadas conductas delictivas, o buscan someterla a modalidades de castigo adicionales a la privación de la libertad en sí misma

En determinadas circunstancias, la Corte IDH también ha considerado que la violencia sexual contra la mujer constituye una violación al artículo 5.2 de la Convención Americana ${ }^{34}$. En este contexto normativo, el Tribunal Interamericano ha calificado la violación sexual realizada por un agente del estado como un acto de violencia sexual especialmente grave y reprobable, dada la vulnerabilidad de la víctima y el abuso del poder que despliega el agente, dirigido a intimidar, degradar, humillar, castigar o controlar a la persona que lo sufre, lo cual permite su calificación como tortura. ${ }^{35}$

Esta calificación de la violación sexual como tortura es también resultado del trauma que genera para quien la sufre y por el hecho de que puede tener severas consecuencias y causar gran daño físico

31 Cfr. Corte IDH Caso Bueno Alves v. Argentina, fondo, reparaciones y costas, sentencia de 11 de mayo de 2007, Serie C No. 164, párr. 79-87; Caso J. v. Perú, excepción preliminar, fondo, reparaciones y costas, sentencia de 27 de noviembre de 2013, Serie C No. 275, párr. 364.

32 Cfr. Corte IDH caso Maritza Urrutia v. Guatemala, fondo, reparaciones y costas, sentencia de 27 de noviembre de 2003, Serie C No. 103, párr. 92; Caso J. Vs. Perú, excepción preliminar, fondo, reparaciones y costa Sentencia de 27 de noviembre de 2013 Serie C No. 275 párr. 364.

33 Cfr. Corte IDH Caso Cantoral Benavides Vs. Perú, fondo, sentencia de 18 de agosto de 2000, Serie C No. 69, párr. 104.

34 Cfr. Corte IDH Caso del Penal Miguel Castro Vs. Perú, fondo, reparaciones y costas, sentencia de 25 de noviembre de 2006, Serie C No. 160, párr. 306.

${ }_{35}$ Cfr. Corte IDH Caso Fernández Ortega y otros Vs. México, excepción preliminar, fondo, reparaciones y costas, sentencia de 30 de agosto de 2010, Serie C No. 215, párr. 127 y 128; Caso Rosendo Cantú y otra Vs. México, excepción preliminar, fondo, reparaciones y costas, sentencia de 31 de agosto de 2010, Serie C No. 216, párr. 117. 
y psicológico, lo cual deja a la víctima humillada física y emocionalmente, situación que es difícilmente superable por el paso del tiempo. ${ }^{36}$

Con base en lo anterior, y tomando en cuenta lo dispuesto en el artículo 2 de la Convención contra la Tortura, la Corte IDH ha estimado que los actos de violencia sexual, por sus efectos, constituyen un acto de tortura. ${ }^{37}$

\section{IV.1.A. Concepto de Tratos o penas crueles, inhumanos y degradantes conforme a la jurisprudencia de la Corte Interamericana de Derechos Humanos}

La Corte IDH ha especificado respecto de las condiciones de detención que de conformidad con el artículo 5.1 y 5.2 de la Convención Americana, toda persona privada de libertad tiene derecho a vivir en una situación de detención compatible con su dignidad personal, lo cual debe ser asegurado por el estado en razón de que este se encuentra en posición especial de garante con respecto a dichas personas, ya que las autoridades penitenciarias ejercen un control total sobre estas ${ }^{38}$. En particular, ha considerado que la detención en condiciones de hacinamiento, con falta de ventilación y luz natural, sin cama para el reposo, sin una higiene adecuada, constituye una violación a la integridad personal ${ }^{39}$. En el mismo sentido, las condiciones de sobrepoblación, la ausencia de una buena alimentación, la falta de oportunidades para hacer ejercicio o realizar actividades recreativas y no contar con atención médica, dental o psicológica, conlleva a condiciones infrahumanas y degradantes que afectan la salud

36 Cfr. Corte IDH Caso del Penal Miguel Castro Vs. Perú, fondo, reparaciones y costas, sentencia de 25 de noviembre de 2006, Serie C No 160, párr. 306 y 311; Caso Fernández Ortega y otros v. México, excepción preliminar, fondo, reparaciones y costas, sentencia de 30 de agosto de 2010, Serie C No. 215, párr. 119.

37 En el caso del Penal Miguel Castro y Castro, la Corte IDH determinó que los actos de violencia sexual a que fue sometida una interna bajo supuesta inspección vaginal dactilar constituyeron una violación sexual. Cfr. Caso del Penal Miguel Castro v. Perú, fondo, reparaciones y costas, Sentencia de fecha 25 de noviembre de 2006, Serie C No 160, párr. 312.

38 Cfr. Corte IDH Caso Caesar Vs. Trinidad y Tobago, fondo, reparaciones y costas, sentencia de 11 de marzo de 2005, Serie C No. 123, párr. 97; Caso Tibi v. Ecuador, excepciones preliminares, fondo, reparaciones y costas, sentencia de 7 de septiembre de 2004, Serie C No. 114, párr. 150.

39 Cfr. Corte IDH Caso Fermín Ramírez Vs. Guatemala., fondo, reparaciones y costas, sentencia de 20 de junio de 2005, Serie C No. 126, párr. 118; Caso Lori Berenson Mejía v. Perú, fondo, reparaciones y costas, sentencia de 25 de noviembre de 2004, Serie C No. 119, párr. 102 
mental, repercutiendo desfavorablemente en el desarrollo psíquico de la vida e integridad personal de la víctima. ${ }^{40}$

La Corte IDH ha determinado que la incomunicación durante la detención y el aislamiento en celda reducida, sin ventilación ni luz natural, con restricciones al régimen de visitas, constituyen formas de tratos crueles, inhumanos o degradantes en el sentido del artículo 5.2 de la Convención Americana ${ }^{41}$ Asimismo ha establecido que el "aislamiento prolongado y la incomunicación coactiva son, por sí mismos, tratamientos crueles e inhumanos, lesivos de la integridad psíquica y moral de la persona y del derecho al respeto de la dignidad inherente al ser humano ${ }^{42}$. La incomunicación solo puede utilizarse de una manera excepcional, tomando en cuenta los graves efectos que genera, ya que "el aislamiento del mundo exterior produce en cualquier persona sufrimientos morales y perturbaciones psíquicas que la coloca en una situación de particular vulnerabilidad y acrecienta el riesgo de agresión y arbitrariedad en las cárceles". ${ }^{43}$

Sobre la base de lo plasmado anteriormente podemos decir que el rol de la dignidad está mencionado por el artículo 5.2 de la Convención Americana de Derechos Humanos, pero no contiene una definición de cuáles son las conductas prohibidas. Si bien el artículo 2 de la Convención Americana define a la tortura, pero no hace la distinción con Tratos Crueles Inhumanos y Degradantes, si lo ha hecho la jurisprudencia de la Corte IDH, la cual ha distinguido tortura no solo física sino también psíquica, estableciendo que se entiende por tratos crueles inhumanos y degradantes.

Si bien la tortura ha sido prohibida en el DIDH con carácter absoluto, los "otros tratos" se consideran como una categoría "menos grave" en la violación al derecho a la integridad personal, se ha llegado a sostener que su protección no goza de los mismos niveles de resguardo que la tortura. Nos referimos al debate que suscita la creciente utilización de prácticas de interrogatorio y reclusión que

40 Cfr. Corte IDH Caso "Instituto de Reeducación del Menor" Vs. Paraguay, excepciones preliminares, fondo, reparaciones y costas, sentencia de 2 de septiembre de 2004, Serie C No. 112, párr. 166 y 168.

41 Cfr. Corte IDH Caso Loayza Tamayo Vs. Perú, fondo, sentencia de 17 de septiembre de 1997, Serie C No. 33, párr. 57 y 58.

42 Cfr. Corte IDH Caso Maritza Urrutia Vs. Guatemala, fondo, reparaciones y costas, sentencia de 27 de noviembre de 2003, Serie C No. 103, párr. 87; Caso Bámaca Velásquez v. Guatemala, fondo, sentencia de 25 de noviembre de 2000, Serie C No. 70, párr. 150.

43 Cfr. Corte IDH Caso Cantoral Benavides Vs. Perú, fondo, Sentencia del 8 de agosto del 2000, Serie C no 69, párr. 84; Caso Lori Berenson Mejía v. Perú, fondo, reparaciones y costa, Sentencia del 25 de noviembre de 2004, Serie C No 119, párr. 104. 
bordean los límites de la protección del derecho a la integridad, técnicas implementadas especialmente en la investigación del crimen organizado o terrorismo. En la discusión existen argumentos a favor y en contra de extender la prohibición absoluta de la tortura a los otros tratos. ${ }^{44}$

\section{IV.2. La prohibición absoluta de la tortura y su pertenencia al dominio del ius cogens internacional en la jurisprudencia de la Corte Interamericana de Derechos Humanos}

\section{IV.2.A. Planteamiento general}

En esta parte del trabajo en primer lugar vamos a definir qué se entiende por ius cogens internacional, y luego analizaremos la prohibición absoluta de tortura y otros tratos crueles a personas privadas de libertad y su pertenencia al dominio del ius cogens conforme a la jurisprudencia de la Corte IDH.

44 World Report, Events of 2005. Human Right Watch: Política de tortura: La administración Bush afirma que no usa ni aprueba la tortura. Sin embargo, su definición de tortura sigue sin estar clara. A finales de 2004, el Departamento de Justicia (DOJ) emitió un memorando en el que repudiaba las políticas anteriores que habían permitido una amplia gama de tácticas brutales de interrogatorio, entre otras maniobras legales, redefiniendo la tortura para excluir todas las técnicas que no infligían dolor "equivalente en intensidad al dolor que acompaña a una lesión física grave, como insuficiencia orgánica, deterioro de las funciones corporales o incluso la muerte". Sin embargo, el departamento nunca ha revelado cuál es su definición actualmente. Las técnicas de interrogatorio autorizadas por la Agencia Central de Inteligencia (CIA) aparentemente incluyen un método notorio que la administración ha rebautizado como "waterboarding" (cuando lo practicaban las dictaduras latinoamericanas, se llamaba "el submarino"): sumergir a la fuerza la cabeza de un sospechoso en agua o hacerle creer. está a punto de ahogarse. El director de la CIA ha declarado que el submarino es una "técnica de interrogatorio profesional". Como se señaló anteriormente, la Administración Bush afirma que las obligaciones de los tratados estadounidenses de abstenerse de tratos crueles, inhumanos y degradantes (CID) no se aplican a la conducta del personal estadounidense no militar que interroga a persona no estadounidenses. ciudadanos fuera de los Estados Unidos. Dirigida por el vicepresidente Cheney, la administración Bush resistió enérgicamente los esfuerzos del Congreso para fortalecer la prohibición legal contra la tortura. Una medida propuesta por el senador republicano John McCain para prohibir la tortura y otros malos tratos a los detenidos en cualquier lugar por parte del ejército de EE. UU. Y la CIA fue aprobada por 90-9 en el Senado, pero al momento de escribir este artículo no había sido aprobada por el Congreso en pleno, al menos en parte porque de objeciones de la administración. Disponible<http://www.hrw. org/> [consutado, 25/04/2021]. 
El ius cogens internacional es definido por el artículo 53 de la Convención de Viena ${ }^{45}$ de 1969 , aunque no en forma directa, “... Como aquella norma imperativa de derecho internacional general, que debe ser aceptada y reconocida por la comunidad internacional de Estados en su conjunto que no admite acuerdo en contrario y que solo puede ser modificada por una norma ulterior de derecho internacional general que tenga el mismo carácter". Por otro lado, el artículo 64 de la Convención de los tratados, en concordancia con el 53, otorga una naturaleza evolutiva al ius cogens al consagrar que "Si surge una nueva norma imperativa de derecho internacional general, todo tratado existente que esté en oposición con ese precepto se convertirá en nulo".

Teniendo en cuenta la definición normativa contemplada en el artículo 53 de la Convención de Viena, analizaremos la pertenencia de la tortura al ius cogens internacional, la cual ha sido ampliamente desarrollada por la doctrina y la jurisprudencia de los tribunales internacionales de derechos humanos. Podemos mencionar que Carrillo Salcedo ${ }^{46}$, señala: «La noción jurídica de la dignidad de la persona proclamada en la Carta de las Naciones Unidas expresa una aspiración ética que ha contribuido a dar concreción y precisión legal a las nociones de ius cogens y de obligaciones erga omnes, categorías que han ido entrando progresivamente en la doctrina y en la práctica internacionales ante la necesidad de establecer barreras objetivas, inspiradas en la idea de humanidad, frente a la pretendida omnipotencia de la voluntad de los estados en derecho internacional». En relación con la norma internacional que prohíbe la tortura, tiene un doble carácter es decir es imperativa y al mismo tiempo es convencional. Su naturaleza de norma imperativa o norma del ius cogens, significa que es una norma de derecho internacional general reconocida y aceptada por la comunidad de estados en su conjunto

45 Convención de Viena del 23 de mayo de 1969, articulo 53 Tratados que están en oposición con una norma imperativa de derecho internacional general (ius cogens). Es nulo todo tratado que, en el momento de su celebración. esté en oposición con una norma imperativa de derecho internacional general. Para los efectos de la presente Convención, una norma imperativa de derecho internacional general es una norma aceptada y reconocida por la comunidad internacional de Estados en su conjunto como norma que no admite acuerdo en contrario y que solo puede ser modificada por una norma ulterior de derecho internacional general que tenga el mismo carácter. Artículo 64. Aparición de una nueva norma imperativa de derecho internacional general ("ius cogens"). Si surge una nueva norma imperativa de derecho internacional general, todo tratado existente que esté en oposición con esa norma se convertirá en nulo y terminar.

46 CARRILLO SALCEDO, J Soberanía de los Estados y Derechos Humanos en Derecho Internacional Contemporáneo. Madrid (Ed. Tecnos), 2001, p. 150. 
como norma que no admite acuerdo en contrario- se deriva de su inclusión en lo que se ha denominado "el núcleo inderogable" de los derechos humanos: aquellos que no pueden ser objeto de restricción, limitación ni reserva incluso en situaciones excepcionales ${ }^{47}$. La tortura y las penas o tratos crueles inhumanos o degradantes están prohibidos en el derecho internacional contemporáneo con carácter absoluto, en el sentido que no puede ser objeto de derogación ni siquiera en caso de peligro público para la vida de la nación ${ }^{48}$.

Por su parte Cancado Trindade ${ }^{49}$ señala que «Se ha conformado una normativa internacional de prohibición absoluta de todas las formas de Tortura, tanto física como psicológica, régimen que pertenece al dominio del ius cogens internacional».

La prohibición absoluta de la tortura alcanza su mayor expresión en el reconocimiento de que ella pertenece hoy en día al dominio del ius cogens internacional. En la jurisprudencia de la Corte este logro internacional, que se ha conseguido tiene consecuencias importantes desde el punto de vista de su exigibilidad, como veremos en los siguientes casos.

\section{IV.2.B. Tortura}

El caso Barrios Altos c/. Perú ${ }^{50}$, el cual se refiere a la responsabilidad internacional del estado por la muerte y lesiones de un grupo de personas por parte de agentes militares, así como la falta de investigación y sanción de los responsables de los hechos. Este caso fue de gran importancia porque por primera vez la Corte IDH se aproxima al concepto de ius cogens con relación a la tortura, sin hacer una referencia expresa a dicho concepto, prefiere proceder al uso de la palabra "inderogable". Resulta esclarecedor el voto del juez Cançado Trindade en esta sentencia, en el cual plantea

47 FERNANDEZ DE CASADEVANTE ROMANI C, Derecho Internacional de los Derechos Humanos. Madrid (Ed. Dilex, S.L.), 2003, p. 40.

48 VID SALADO OSUNA, A. Los Tortura y otros tratos prohibidos por el Convenio Europeo de Derechos Humanos, en GARCIA ROCA, J Y SANTOLAYA, P, La Europa de los Derechos: el Convenio Europeo de Derechos Humanos, $2^{\mathrm{a}}$ Ed, Madrid, (Centro de estudios políticos y constitucionales), 2009, p.107.

49 CANCADO, TRINDADE A, "Derecho internacional para la humanidad: hacia un nuevo ius Gentium - Curso general de derecho internacional público - Parte I", Colección 316 de cursos de la Academia de Derecho Internacional de La Haya (2005), cap. XII, pp. 336-346.

50 Cfr. Corte IDH, caso Barrios Altos Vs. Perú, fondo, reparaciones y costas. Sentencia del 14 de marzo de 2001, Serie C no 175. 
que las leyes de autoamnistía no solo carecen de efectos jurídicos, sino que constituyen por sí mismas una violación a los artículos 1,2,8 y 25 de la Convención Americana de Derechos Humanos ${ }^{51}$, y por lo tanto comprometen la responsabilidad internacional de los

51 OEA Convención Americana de Derechos Humanos, San José, Costa Rica promulgada en fecha 7 al 22 de noviembre de 1969. Artículo 1. Obligación de Respetar los Derechos 1. Los Estados Partes en esta Convención se comprometen a respetar los derechos y libertades reconocidos en ella y a garantizar su libre y pleno ejercicio a toda persona que esté sujeta a su jurisdicción, sin discriminación alguna por motivos de raza, color, sexo, idioma, religión, opiniones políticas o de cualquier otra índole, origen nacional o social, posición económica, nacimiento o cualquier otra condición social.2. Para los efectos de esta Convención, persona es todo ser humanos. Artículo 2. Deber de Adoptar Disposiciones de Derecho Interno Si el ejercicio de los derechos y libertades mencionados en el artículo 1 no estuviere ya garantizado por disposiciones legislativas o de otro carácter, los Estados Partes se comprometen a adoptar, con arreglo a sus procedimientos constitucionales y a las disposiciones de esta Convención, las medidas legislativas o de otro carácter que fueren necesarias para hacer efectivos tales derechos y libertades. Artículo 8. Garantías Judiciales 1 . Toda persona tiene derecho a ser oída, con las debidas garantías y dentro de un plazo razonable, por un juez o tribunal competente, independiente e imparcial, establecido con anterioridad por la ley, en la sustanciación de cualquier acusación penal formulada contra ella, o para la determinación de sus derechos y obligaciones de orden civil, laboral, fiscal o de cualquier otro carácter. 2. Toda persona inculpada de delito tiene derecho a que se presuma su inocencia mientras no se establezca legalmente su culpabilidad. Durante el proceso, toda persona tiene derecho, en plena igualdad, a las siguientes garantías mínimas: a) derecho del inculpado de ser asistido gratuitamente por el traductor o intérprete, si no comprende o no habla el idioma del juzgado o tribunal; b) comunicación previa y detallada al inculpado de la acusación formulada) concesión al inculpado del tiempo y de los medios adecuados para la preparación de su defensa, d) derecho del inculpado de defenderse personalmente o de ser asistido por un defensor de su elección y de comunicarse libre y privadamente con su defensor; e) derecho irrenunciable de ser asistido por un defensor proporcionado por el Estado, remunerado o no según la legislación interna, si el inculpado no se defendiere por sí mismo ni nombraré defensor dentro del plazo establecido por la ley; f) derecho de la defensa de interrogar a los testigos presentes en el tribunal y de obtener la comparecencia, como testigos o peritos, de otras personas que puedan arrojar luz sobre los hechos; g) derecho a no ser obligado a declarar contra sí mismo ni a declararse culpable, y h) derecho de recurrir del fallo ante juez o tribunal superior.3. La confesión del inculpado solamente es válida si es hecha sin coacción de ninguna naturaleza. 4. El inculpado absuelto por una sentencia firme no podrá ser sometido a nuevo juicio por los mismos hechos. 5. El proceso penal debe ser público, salvo en lo que sea necesario para preservar los intereses de la justicia. Articulo 25 Protección judicial 1. Toda persona tiene derecho a un recurso sencillo y rápido o a cualquier otro recurso efectivo ante los jueces o tribunales competentes, que la ampare contra actos que violen sus derechos fundamentales reconocidos por la Constitución, la ley o la presente Convención, aun cuando tal violación sea cometida por personas que actúen en ejercicio de sus funciones oficiales.2. Los Estados Partes se comprometen: a) a garantizar que la autoridad competente prevista por el sistema legal del Estado decidirá sobre los derechos de toda persona que interponga tal recurso; b) a desarrollar las posibilidades de recurso judicial, y c) a garantizar el cumplimiento, por las autoridades competentes, de toda decisión en que se haya estimado procedente el recurso. Disponible 
estados, resultando estas normas incompatibles con la normativa internacional de los derechos humanos, ya que afectan derechos que se consideran inderogables en el ámbito del ius cogens internacional.

A partir del caso Maritza Urrutia c. Guatemala ${ }^{52}$, hasta los casos Cabrera García y Montiel Flores c. México ${ }^{53}$ y Fleury y otros c. Haití ${ }^{4}$, la Corte ha sido clara y ha mantenido una misma línea en su jurisprudencia al considerar que la Tortura es contraria al ius cogens. Agrega que ni siquiera en las situaciones más difíciles, como la lucha contra el terrorismo se puede justificar este delito. En este sentido la Corte empezó diciendo que "Se ha conformado un régimen jurídico internacional de prohibición absoluta de todas las formas de tortura, tanto física como psicológica, y respecto a esta última, se ha reconocido que las amenazas y el peligro real de someter a una persona a lesiones físicas produce, en determinadas circunstancias, una angustia moral de tal grado que puede ser considerada `tortura psicológica" 55 .

La prohibición absoluta de la tortura, es completa e inderogable en todas sus formas, pertenece hoy en día al dominio de ius cogens internacional, es decir que el derecho a la integridad física y psíquica de las personas privadas de la libertad no puede ser suspendido, aun en las circunstancias más difíciles, tales como guerra, amenaza de guerra, lucha contra el terrorismo y cualesquiera otros delitos, estado de sitio o de emergencia, conmoción o conflicto interior, suspensión de garantías constitucionales, inestabilidad política interna u otras emergencias o calamidades públicas". ${ }^{56}$

en <https://www.oas.org/dil/esp/tratados_b-32_convencion_americana_sobre_derechos_humanos.htm $>$ [consultado en fecha 11/11/2019]

${ }_{52}$ Cfr. Corte IDH, caso Maritza Urrutia Vs. Guatemala, fondo, reparaciones y costas. Sentencia del 27 de noviembre de 2003. Serie C No 103, párr. 92.

53 Cfr. Corte IDH, Caso Cabrera García y Montiel Flores Vs. México, fondo, reparaciones y costas, sentencia del 26 de noviembre de 2010, Serie C No 220.

54 Cfr. Corte IDH, Caso Fleury y otros Vs. Haití, fondo, reparaciones, sentencia de fecha 23 de noviembre de 2011, Serie C No 236.

55 Cfr. Corte IDH; caso Cantoral Benavides Vs. Perú. Sentencia del 18 de agosto de 2000. Serie C No 69, párr. 102. Cfr. Corte IDH; caso Maritza Urrutia Vs. Guatemala. Sentencia del 27 de noviembre de 2003. Serie C No 103 párr. 92. Corte IDH caso de los Hermanos Gómez Paquiyauri Vs. Perú. Sentencia del 8 de julio de 2004. Serie C No 110 párr. 112. Corte IDH; caso Fermín Ramírez Vs. Guatemala. Sentencia del 20 de junio de 2005. Serie C No 126 párr. 117. Corte IDH; caso Servellón García y otro Vs. Honduras. Sentencia del 21 de septiembre de 2006, Serie C No 152 párr. 97. Corte IDH; caso de la Masacre de la Rochela Vs. Colombia. Sentencia del 11 de mayo de 2007, Serie C No 163, párr. 132.

56 Cfr. Corte IDH; caso Tibi Vs. Ecuador, Sentencia del 7 de septiembre de 2004. Serie C No 114 párr. 143. Corte Interamericana de Derechos Humanos; caso De la Cruz Flores c. Perú, Sentencia del 18 de noviembre de 2004. Serie C No 115 
En igual sentido en el caso del Penal Miguel Castro Vs. Perú $u^{57}$, en el cual se responsabilizó internacionalmente al estado por la utilización excesiva de la fuerza que resultó la muerte de decenas de presos, así como de numerosos heridos en el marco de un operativo en el centro penitenciario Miguel Castro, dadas las circunstancias en las que ocurrieron los hechos, la Corte determinó que las muertes y las torturas se enmarcan como crimen de lesa humanidad; así mismo reitera el carácter de ius cogens de la tortura.

En esta misma orden de ideas la Corte Interamericana en el caso Buenos Alves c. Argentina ${ }^{58}$, es interesante apreciar como en este caso logra decantar su abundante jurisprudencia sobre este tema y extraer los elementos constitutivos de la tortura, señalando que se requieren tres elementos para que se configure la tortura, estos son: a) un acto intencional; b) que cause severos sufrimientos físicos o mentales, y c) que se cometa con determinado fin o propósito. Sin embargo, en el caso González y Otras ("Campo Algodonero") c. México, la jueza Cecilia Medina Quiroga, en su voto razonado, hace un análisis de los elementos de la tortura de acuerdo con los parámetros de la Corte Penal para la antigua Yugoslavia - TPIY que los divide en tres que hacen parte del ius cogens y otros tres que no lo son. En este sentido se señala que i) el sufrimiento o dolor intensos, físicos o mentales, ya sea por acción u omisión; ii) la intencionalidad del acto y iii) la motivación o fin del acto para conseguir algo tienen carácter imperativo; mientras que i) la lista de motivaciones por las cuales el acto se comete; ii) la necesidad de que el acto se cometa en conexión con un conflicto armado, y iii) el requisito de que el acto sea perpetrado o sea instigado por un agente del Estado o se realice con su consentimiento o aquiescencia no hacen parte del ius cogens. En este sentido, la jueza Medina hace la presente comparación para determinar si la Corte debe aplicar la Convención Interamericana para Prevenir y Sancionar la Tortura - CIPST o la Convención contra la Tortura. Sin embargo, concluye que lo que se debe aplicar como definición y alcance es él ius cogens por ser más garantista. Como el CIPST permite que haya leyes especiales y al ser más garantista la

párr. 125. Corte IDH; caso Lori Berenson Mejía Vs. Perú, Sentencia del 25 de noviembre de 2004. Serie C No 119 párr. 100. Corte IDH; caso García Asto y Ramírez Rojas Vs. Perú, Sentencia del 25 de noviembre de 2005. Serie C No 137 párr. 222. Corte IDH; caso Baldeón García Vs. Perú, Sentencia del 6 de abril de 2006. Serie C No 147, párr. 117.

57 Cfr. Corte IDH; caso del Penal Miguel Castro Vs. Perú, Sentencia del 25 de noviembre de 2006. Serie C No 160, párr. 404.

58 Cfr. Corte IDH caso Bueno Alves Vs. Argentina. Fondo, reparación y costas. Sentencia del 11 de mayo 2007, Serie C No 164. 
norma inderogable, no hay problema. Es más, al estar consagrada la excepción de leyes especiales, lo que se aplica es la CIPST misma al aplicar él ius cogens por ser más garantista ${ }^{59}$.

\section{IV.2.C. Tratos Crueles Inhumanos o Degradantes}

Si bien la tortura y los tratos o penas crueles inhumanos y degradantes generalmente han evolucionado de manera conjunta, decidimos separarlos en el presente trabajo para determinar si hay alguna diferencia entre ellos bajo la perspectiva del desarrollo progresivo del derecho internacional. Para la Corte es claro, tal y como ocurre con la tortura, que estos tratos hacen parte de las normas de ius cogens. En términos generales, la Corte ha sido constante conceptualmente hablando en lo relativo a este delito y en este sentido podemos identificar cuatro bloques de decisiones. En primer lugar, podemos citar el caso Caesar del año 2005. En este se hace referencia a normas perentorias ${ }^{60} \mathrm{y}$ unos párrafos más adelante los identifica como de ius cogens en forma directa ${ }^{61}$, es decir, en la misma sentencia identifica los dos conceptos. En segundo lugar, tenemos los casos Ximenes López. ${ }^{62}$ y la Masacre de la Rochela ${ }^{63} \mathrm{en}$ los que la Corte hace una referencia clara y expresa a que los tratos crueles, inhumanos o degradantes "pertenecen hoy día al dominio del ius cogens". En tercer lugar, tenemos los casos Montero Aranguren, Servellón García y el conocido como "Campo Algodonero" en los que la Corte hace referencia a estos tratos como derechos que "forman parte del núcleo inderogable" 64 en la medida que no puede ser suspendido en ningún momento. La imposibilidad de suspender el derecho a la integridad personal no solo la Corte IDH, lo ha reconocido en sus sentencias, al

59 Cfr. Corte IDH caso Bueno Alves Vs. Argentina. Fondo, reparación y costas. Sentencia del 11 de mayo 2007 Serie C No 164.

60 Corte Interamericana de Derechos Humanos; caso Vs. Trinidad y Tobago, Sentencia del 11 de marzo de 2005. Serie C No 123.

${ }_{61}$ Cfr. Corte IDH, caso Caesar Vs. Trinidad y Tobago, Sentencia del 11 de marzo de 2005. Serie C No 123 párr. 100.

62 Cfr. Corte IDH, caso Ximenes López Vs. Brasil, 4 de julio de 2006 Serie C No 149.

63 Cfr. Corte IDH, caso Masacre de Rochela Vs Colombia, fondo reparación y costas sentencia de fecha 11 de mayo de 2007 Serie C No 163.

64 Cfr. Corte IDH; caso Montero Aranguren y otros ("Retén de Catia") Vs. Venezuela, Sentencia del 5 de julio de 2006. Serie C No 150 párr. 85. Corte Interamericana de Derechos Humanos; caso Servellón García y otros Vs. Honduras, Sentencia del 21 de septiembre de 2006. Serie C No 152 párr. 97. Corte Interamericana de Derechos Humanos; caso González y otras ("Campo Algodonero") Vs. México, Sentencia del 16 de noviembre de 2009. Serie C No 152 párr. 244. 
declararlo inderogable, sino que sé, desprende en primer lugar del artículo 27.2 de la Convención Americana, que prevé cuáles son esos derechos que no pueden suspenderse nunca entre ellos figura la integridad personal prevista en el artículo 5 de dicha Convención, también la inderogabilidad se encuentra contemplada por el artículo 2 de la Convención contra la Tortura y del artículo 4.2 del Pacto de Derechos Civiles y Políticos. Es decir que la inderogabilidad no es una creación pretoriana sino convencional.

En esta orden de ideas la Corte IDH en el caso Montero Aranguren señala que el derecho a la integridad personal no puede ser suspendido "en casos de guerra, peligro público u otras amenazas a la independencia o seguridad de los estados partes. En tal sentido, los estados no pueden alegar dificultades económicas para justificar condiciones de detención que sean tan pobres que no respeten la dignidad inherente del ser humano" 65 .

Finalmente, en el caso de La Masacre de las Dos Erres, la Corte une los dos conceptos y afirma que estos tratos "contravienen normas inderogables (ius cogens)". Este caso es interesante en la medida en que se incluye de manera expresa, como un hecho grave contra la integridad personal, la violencia sexual en conflictos armados o dentro de patrones sistemáticos. Además, como lo veremos más adelante, señala que la violación de estas obligaciones "generan obligaciones para los Estados como la de investigar y sancionar dichas prácticas" 66 .

\section{DEBERES Y OBLIGACIONES DEL ESTADO ANTE CASOS DE TORTURA Y OTROS TRATOS O PENAS CRUELES, INHUMANOS Y DEGRADANTES PADECIDOS POR PERSONAS PRIVADAS DE LA LIBERTAD}

\section{V.1. Deber de investigar}

La Corte IDH ha reafirmado que el deber de investigar es una obligación estatal imperativa que deriva del derecho internacional y no puede verse atenuada por actos o disposiciones de normativas

65 Cfr. Corte IDH; caso Montero Aranguren y otros ("Retén del Catia") Vs. Venezuela, Sentencia del 5 de julio de 2006. Serie C No 150 párr. 85.

66 Cfr. Corte IDH; caso de la Masacre de la Dos Erres Vs. Guatemala, Sentencia del 24 de noviembre de 2009. Serie C No 211, párr. 140. 
internas de ninguna índole. ${ }^{67}$ Además ha especificado que este deber surge tan pronto como las autoridades estatales tienen conocimiento de que existen denuncias o motivos para creer que ha ocurrido un acto de tortura, en cuyo caso deben iniciar de oficio y sin dilación, una investigación seria, imparcial y efectiva. La misma debe realizarse utilizando todos los medios legales disponibles y debe estar orientada a la determinación de la verdad, persecución, captura, enjuiciamiento y castigo de todos los responsables de los hechos. ${ }^{68}$

En esta orden de ideas en su plexo jurisprudencial la Corte IDH ha señalado que de conformidad con el artículo 1.1 de la Convención Americana, la obligación de los estados de garantizar los derechos reconocidos en los artículos 5.1 y 5.2 de la Convención Americana, es decir el deber de investigar posibles actos de tortura u otros tratos crueles, inhumanos o degradantes. Además, de acuerdo con lo dispuesto en el artículo 8 de esta Convención, cuando exista denuncia o razón fundada para creer que se ha cometido un acto de tortura en el ámbito de su jurisdicción, los estados partes garantizarán que sus respectivas autoridades procederán de oficio y de inmediato a realizar una investigación sobre el caso y a iniciar, cuando corresponda, el respectivo proceso penal. ${ }^{69}$

67 En particular, la Convención Americana, el artículo 1 formula la obligación general de prevenir la tortura. El Artículo 6 exige que los estados partes criminalicen los actos de tortura y los intentos de cometerlos, conforme a sus derechos penales nacionales asimismo que castiguen la tortura con sanciones severas que reflejen la gravedad del delito. Igualmente, los estados deben adoptar medidas efectivas para prevenir y sancionar otros tratos o penas crueles, inhumanos y degradantes dentro del ámbito de sus respectivas jurisdicciones. El Artículo 7 obliga a los estados a entrenar a los policías y otros funcionarios públicos responsables de la custodia de los detenidos en relación con la prohibición de la tortura y otros tratos crueles, inhumanos o degradantes. En función de la Convención, la Corte IDH ha concluido que se han infligido los Artículos 1 y 6 de la Convención Interamericana para Prevenir y Sancionar la Tortura en ocasiones en las que un estado parte no ha procedido con la debida diligencia para prevenir la tortura y otros malos tratos dentro del ámbito de su jurisdicción. La Corte IDH establece que el deber de prevención por parte de los estados abarca todas aquellas medidas de carácter jurídico, político, administrativo y cultural que promuevan salvaguardar los derechos humanos y que aseguren que las eventuales violaciones a los mismos sean efectivamente consideradas y tratadas como un hecho ilícito, susceptible de acarrear sanciones para quien las cometa, así como la obligación de indemnizar a las víctimas por sus consecuencias perjudiciales.

68 Cfr. Corte IDH, Caso Montero Aranguren y otros (Retén de Catia) Vs. Venezuela, fondo, reparaciones y costas, sentencia de 5 de julio de 2006, Serie C No. 150, párr. 79; Caso Ximenes Lopes Vs. Brasil, fondo, reparaciones y costas, sentencia de 4 de julio de 2006, Serie C No. 149, párr. 148.

${ }_{69}$ Cfr. Corte IDH caso Bayarri Vs. Argentina. Excepción Preliminar, Fondo, Reparaciones y Costas. Sentencia de 30 de octubre de 2008 Serie C No 187. 
En igual sentido en el Caso del Penal Miguel Castro Vs. Perú, ${ }^{70}$ la Corte ha establecido que el estado es responsable, en su condición de garante por las torturas, tratos crueles, inhumanos o degradantes que sufre una persona que ha estado bajo la custodia de agentes estatales, si las autoridades no han realizado una investigación seria de los hechos seguida del procesamiento de quienes aparezcan como responsables de ellos.

La Corte ha establecido que el estado es responsable, en su condición de garante de los derechos consagrados en la Convención, de la observancia de los derechos a la vida y a la integridad personal de todo individuo que se encuentre bajo su custodia. Puede considerarse responsable al estado por los tratos crueles, inhumanos o degradantes que sufre una persona que ha estado bajo la custodia de agentes estatales, o que ha fallecido en tales circunstancias, cuando las autoridades no han realizado una investigación seria de los hechos seguida del procesamiento de los responsables. En tal sentido, recae en el estado la obligación de proveer una explicación inmediata, satisfactoria y convincente de lo sucedido a una persona que se encontraba bajo su custodia, y desvirtuar las alegaciones sobre su responsabilidad, mediante elementos probatorios. ${ }^{71}$

\section{V.2. Deber de prevención}

La Convención Interamericana para Prevenir y Sancionar la Tortura establece el deber de los estados partes de adoptar medidas para prevenir la tortura ${ }^{72}$. En particular, el artículo 1 formula la

70 Cfr. Corte IDH caso de la Corte IDH Caso del Penal Miguel Castro Vs. Perú. Fondo, Reparaciones y Costas. Sentencia de 25 de noviembre de 2006, Serie C No 160.

71 Cfr. Corte IDH caso Vera y otra Vs. Ecuador, excepción preliminar, fondo, reparaciones y costas, sentencia del 19 de mayo de 2011 Serie C No 226.

72 Convención Interamericana para prevenir y sancionar la tortura, Asamblea General de la Organización de Estados Americanos Cartagena de Indias; Colombia, 9 de diciembre de 1985. Entro en vigencia el 28 de febrero de 1987. Artículo 1. Los Estados partes se obligan a prevenir y a sancionar la tortura en los términos de la presente Convención. Artículo 6. De conformidad con lo dispuesto en el artículo 1, los Estados partes tomarán medidas efectivas para prevenir y sancionar la tortura en el ámbito de su jurisdicción. Los Estados partes se asegurarán de que todos los actos de tortura y los intentos de cometer tales actos constituyan delitos conforme a su derecho penal, estableciendo para castigarlos sanciones severas que tengan en cuenta su gravedad. Igualmente, los Estados partes tomarán medidas efectivas para prevenir y sancionar, además, otros tratos o penas crueles, inhumanos o degradantes en el ámbito de su jurisdicción. Artículo 7. Los Estados partes tomarán medidas para que, en el adiestramiento de agentes de la policía y de otros fun- 
obligación general de prevenir la tortura. El Artículo 6 exige que los estados partes criminalicen los actos de tortura y los intentos de cometerlos, conforme a sus derechos penales nacionales asimismo que castiguen la tortura con sanciones severas que reflejen la gravedad del delito. Igualmente, los estados deben adoptar medidas efectivas para prevenir y sancionar otros tratos o penas crueles, inhumanos y degradantes dentro del ámbito de sus respectivas jurisdicciones. El Artículo 7 obliga a los estados a entrenar a los policías y otros funcionarios públicos responsables de la custodia de los detenidos en relación con la prohibición de la tortura y otros tratos crueles, inhumanos o degradantes. En función de la Convención, la Corte IDH ha concluido que se han infligido los Artículos 1 y 6 de la Convención Interamericana para Prevenir y Sancionar la Tortura en ocasiones en las que un estado parte no ha procedido con la debida diligencia para prevenir la tortura y otros malos tratos dentro del ámbito de su jurisdicción. ${ }^{73}$

La Corte IDH establece que el deber de prevención por parte de los estados abarca todas aquellas medidas de carácter jurídico, político, administrativo y cultural que promuevan salvaguardar los derechos humanos y que aseguren que las eventuales violaciones a los mismos sean efectivamente consideradas y tratadas como un hecho ilícito, susceptible de acarrear sanciones para quien las cometa, así como la obligación de indemnizar a las víctimas por sus consecuencias perjudiciales ${ }^{74}$. Es claro, a su vez, que el deber de prevenir es de medio o comportamiento y no se demuestra su incumplimiento por el mero hecho de que un derecho haya sido violado ${ }^{75}$.

cionarios públicos responsables de la custodia de las personas privadas de su libertad, provisional o definitivamente, en los interrogatorios, detenciones o arrestos, se ponga especial énfasis en la prohibición del empleo de la tortura Igualmente, los Estados partes tomarán medidas similares para evitar otros tratos o penas crueles, inhumanos o degradantes disponible en < https://www.oas.org/juridico/spanish/ tratados/a-51.html $>$ [consultado el 20/10/2020].

73 Cfr. Corte IDH Caso Tibi Vs. Ecuador, sentencia del 7 de septiembre de 2004.-; Caso Gómez Paquiyauri, Vs. Perú sentencia del 8 de julio de 2004 En especial, el Tribunal Interamericano ha advertido que "La sustracción de elementos que se consideran irreductibles en la fórmula persecutoria establecida a nivel internacional, así como la introducción de modalidades que resten sentidos o eficacia pueden llevar a la impunidad de comportamientos, que los Estados están obligados bajo el derecho internacional a prevenir, erradicar y sancionar la tortura.

74 FERRER MACGREGO, E, "Las siete principales líneas jurisprudenciales de la Corte Interamericana de Derechos Humanos aplicable a la justicia penal", Revista IIDH, n. ${ }^{\circ}$ 59, 2014, pp. 29-118.

75 Cfr. Corte IDH caso Velásquez Rodríguez Vs. Honduras. Sentencia del 29 de julio 1988 Serie C No 4. 
Por lo tanto, se incumple el deber de prevención en aquellos casos en que el estado demandado no ha actuado con la debida diligencia para prevenir una infracción de los derechos consagrados en la Convención. En el contexto de la tortura y otros tratos crueles, inhumanos o degradantes, la Corte en el caso Velásquez Rodríguez concluyó que aunque no era posible demostrar que la víctima hubiese sido sometida a tormentos, "La mera circunstancia de cuyo secuestro y cautiverio hayan quedado a cargo de autoridades que comprobadamente sometían a los detenidos a vejámenes, crueldades y torturas representa la inobservancia, por parte de Honduras, del deber que le impone el artículo 1.1, en relación con los párrafos 1 y 2 del artículo 5 de la Convención". ${ }^{76}$ Por consiguiente, la Corte declaró que el estado había violado el derecho a no ser sometido a tortura como resultado de no haber actuado con la debida diligencia para prevenir las violaciones de los derechos humanos del Sr. Velásquez Rodríguez. ${ }^{77}$

La Corte ha declarado recientemente que el deber de prevenir una violación del artículo 5 en lo que respecta a las personas privadas de libertad supone una obligación positiva de garantizar condiciones de detención que respeten las normas básicas mínimas de dignidad humana. Aplicando esta obligación, la Corte encontró a Paraguay responsable de la violación del artículo 5, leído conjuntamente con el Artículo 1 (1) de la Convención Americana, puesto que el Gobierno no garantizó el cumplimiento de las normas básicas mínimas en un centro de rehabilitación de menores ${ }^{78}$.

\section{V.3. Deber de sancionar, cumplir las leyes y excluir las pruebas obtenidas mediante tortura}

El deber de sancionar a los responsables de actos de tortura complementa y refuerza la obligación de respetar y garantizar los derechos establecida en el artículo 1.1 de la Convención Americana ${ }^{79}$. El delito de tortura debe incorporarse en la legislación nacional de conformidad con la definición de tortura del derecho internacional, que

76 Cfr. Corte IDH Caso Velásquez Rodríguez Vs. Honduras. Sentencia del 29 de julio 1988 Serie C No 4, parr.186

77 Ibidem, párr. 187.

78 Cfr. Corte IDH Caso Instituto de reeducación del menor Vs. Paraguay, excepciones preliminares, fondo reparaciones y costas sentencia del 2 de septiembre de 2004 serie No.112.

79 Cfr. Corte IDH Caso Velásquez Rodríguez vs. Honduras, fondo Sentencia del 29 de julio 1988 Serie C No 4 párr. 165 y 166. 
según la Corte IDH establece un estándar mínimo acerca de una correcta tipificación de esta clase de conductas y los elementos mínimos que la misma debe observar. El estado debe investigar seriamente con los medios a su alcance las violaciones que se hallan cometidos dentro del ámbito de su jurisdicción a fin de identificar a los responsables, de imponerles sanciones pertinentes y de asegurar a la víctima una adecuada reparación ${ }^{80}$.

Asimismo, el deber de excluir pruebas obtenidas mediante tortura complementa el derecho al debido proceso en conformidad con el artículo 8 de la Convención Americana ${ }^{81}$. La Corte IDH, en el caso Cantoral Benavides, luego de haber determinado que el denunciante había sido sometido a tormentos físicos y psicológicos con el fin de suprimir su resistencia psíquica y forzarlo a inculparse o a confesar determinadas conductas delictivas ${ }^{82}$, determinó la existencia de una violación del artículo 8 de la Convención Americana, pues las pruebas obtenidas por tortura no constituían una prueba auténtica.

\section{CONCLUSIÓN}

La Corte IDH, desde sus primeras sentencias en el año 1988 hasta la fecha, se ha pronunciado sobre el tema de la integridad y libertad personales de las personas privadas de la libertad.

Durante sus primeros años de funcionamiento la mayoría de casos conocidos por la Corte IDH se han referido a esta temática, así como al derecho a la vida, lo que a su vez le ha permitido crear una extensa y detallada jurisprudencia sobre la materia.

El derecho a la libertad personal, las restricciones de este derecho y el trato que los estados dan a las personas privadas de libertad,

80 Cfr. Corte IDH Caso Goiburú y otros vs. Paraguay, fondo, reparaciones y costas, sentencia de 22 de septiembre de 2006, Serie C No. 153, párr. 92.

${ }_{81}$ Convención Americana de derechos Humanos Pacto de San José de Costa Rica promulgada del 7 al 22 de noviembre de 1969. Articulo 8 El cual establece, en su parte pertinente, que cada individuo tiene "2.g.) Derecho a no ser obligado a declarar contra sí mismo ni a declararse culpable [...] 3. La confesión del inculpado solamente es válida si es hecha sin coacción de ninguna naturaleza "Disponible en $<$. https://www.oas.org/dil/esp/tratados_b-32_convencion_americana_sobre_derechos_humanos.htm > [consultado el 20/10/2020].

${ }_{82}$ Cfr. Corte IDH Caso Cantoral Benavides v. Perú, fondo sentencia del 18 de agosto del 2000, Serie C No 69 párr. 132 y 133; Caso Tibi v. Ecuador, excepciones preliminares, fondo, reparaciones y costa sentencia del 7 de septiembre del 2004, Serie C No 114 párr. 149. 
constituyen unos de los temas de mayor trascendencia actualmente en el ámbito de la protección de los derechos humanos.

La Corte IDH, se ha referido, entre otros, a la detención ilegal, la detención arbitraria, la privación de libertad en estados de emergencia, el derecho de los detenidos a obtener información sobre los motivos de su detención, el derecho a ser llevado sin demora ante un juez, el derecho a ser juzgado dentro de un plazo razonable, el derecho a recurrir ante un juez o tribunal competente y al hábeas corpus frente a situaciones de secuestro. Además, el Tribunal se ha pronunciado, dentro del ámbito de la integridad personal de las personas privadas de libertad, sobre las condiciones de detención, el trato a las personas privadas de libertad, con especial énfasis sobre mujeres y niños en esta situación, medidas de seguridad, administración de las prisiones, pena de muerte, asistencia médica, entre otros. Por otra parte, la Corte IDH, ha establecido en su jurisprudencia, medidas que tienden a reparar específicamente violaciones a la libertad y la integridad personales en el contexto de personas privadas de libertad en prisiones y otros centros de detención.

\section{BIBLIOGRAFÍA}

Álvaro Castro Ciclero, M y Mera, J, Derechos fundamentales de las personas privadas de la libertad, Chile, (Ediciones universidad Diego Portales), 2010.

Bellof, M y Clerico, L, «Derecho a condiciones de existencia digna y situación de vulnerabilidad en la jurisprudencia de la Corte Interamericana», Estudios constitucionales, 2016, PP 139-178 disponible en<https://scielo.conicyt.cl/pdf/estconst/v14n1/art05.pdf > .

Cancado Trindade, A; "Derecho internacional de la humanidad, hacia un nuevo ius Gentium», Editores Martinus Nijhoff, La Haya, 2010 Retomado de: Cançado Trindade, Antônio Augusto; "Derecho Internacional de la Humanidad, hacia un Nuevo ius Gentium", RCADI, Vols. 316-317, Martinus Nijhoff Publishers, La Haya, 2006.

Carillo Salcedo, J. Soberanía de los Estados y derechos humanos en el Derecho Internacional Contemporáneo. Madrid. Ed. Tecno. 2001.

CONSEJO DE EUROPA, Convenio Europeo para la Prevención de la Tortura y de las Penas o Tratos Inhumanos o Degradantes (n. ${ }^{\circ} 126$ del Consejo de Europa), elaborado en Estrasburgo el 26 de noviembre de 1987 entro en vigencia el 5 de julio de 1989. Disponible en <https://dhpedia.wikis.cc/wiki/convenioeuropeo_para_la_ 
prevencio\%C3\%B3n_de_la_Tortura_y_de_las_Penas_o_Tratos_ Inhumanos_o degradantes $>$.

CONSEJO DE EUROPA, Convención Europea de Derechos Humanos. (Tribunal Europeo de Derechos Humanos) fecha 1 de junio de 2010. <Disponible en https://www.echr.coe.int/documents/convention_spa.pdf $>$ [Consultado en fecha 23/11/2020].

CORTE INTERAMERICANA DE DERECHOS HUMANOS Y COOPERACIÓN ALEMANA (GIZ). CUADERNILLO DE JURISPRUDENCIA DE la Corte Interamericana de Derechos Humanos No. 9: Personas PRIVADAS DE LIBERTAD. (SAN JosÉ, Costa Rica), 2020. Disponible en $<$ https://www.corteidh.or.cr/sitios/libros/todos/docs/cuadernillo9. pdf>. [Consultado el 01/12/2020]

Ferrajoli, L, Las libertades en el tiempo del Neoliberalismo isonomía Revista de teoría o filosofía del derecho n. ${ }^{\circ} 29$ (2008) pp 1-15 disponible en <http://www.scielo.org.mx/pdf/is/n29/n29a4.pdf> .

Fernández de Casadevante Romani, C. Derecho Internacional de los Derechos Humanos. Ed. Diles, S.L. (Madrid). 2003.

Ferrer Macgregor, E., «Las siete principales lineas jurisprudenciales de la Corte Interamericana de Derechos Humanos aplicable a la justicia penal», Revista IIDH, n. ${ }^{\circ}$ 59, 2014, pp. 29-118. Foucault, M. Vigilar y Castigar. España, Siglo XXI Editores, 1996.

GARCía MACHO, R., "En torno a las garantías de los Derechos fundamentales en el ámbito de las relaciones de especial sujeción», Revista de Estudios de Derecho Administrativo, Madrid, 1989, menciona a F. TEZNER, «Das freie Ermessen der Verwaltungsbehörden», 1924.

GaRduños SALINAS, C," La finalidad de la Tortura en el derecho internacional Mexicano de Derechos Humanos, Consideraciones para investigación y documentación de la Tortura en México ", OACNUDH (México) 2007.

Nash Rojas, La Concepción de derechos fundamentales en Latinoamérica, ciudad de México (Fontana), p. 197.

Gallego Anabitarte, A, "Las relaciones de especial sujeción y el principio de legalidad de la Administración» en Revista de Derecho Público, n. ${ }^{\circ} 34,1961$, pp. 11 y ss.

Mapelli Caffarena, B., "Las relaciones especiales de sujeción y el sistema penitenciario”, Estudios Penales y Criminológicos (XVI), Santiago de Compostela, (1993). 
O DonNell, D, La Tortura y trato cruel inhumano y degradante, contenido y significado en el derecho Internacional de los Derechos Humanos, Instrumentos Nacionales E internacionales para prevenir y sancionar la tortura (México), secretaria de Relaciones Exteriores, Programa de Cooperación sobre Derechos Humanos /Comisión Europea, 2005. OEA, Convención Interamericana para Prevenir y Sancionar la Tortura, adoptada en la Asamblea General de la Organización de Estados Americanos, $15^{\circ}$ período ordinario de sesiones, Cartagena de Indias, Colombia, el 9 de diciembre de 1985. Entrada en vigor: 28 de febrero de 1987. Disponible en $<\mathrm{http:}$ www.defensoria.org.ar/wp-content/uploads2017/02/conevencionInteramericanaContraTortura.pdf $>$.

ONG, Informe de Amnistía internacional contra la Tortura (Londres) Reino Unido, 2018. Disponible<https://crm.es.amnesty.org/ sites/default/files/civicrm/persist/contribute/files/infomeanua12018air201718-spanish\%20 web.pdf> [Consultado en fecha 13/11/2020].

ONU, Convención contra la Tortura y Otros Tratos o Penas Crueles, Inhumanos o Degradantes, adoptada y abierta a la firma, ratificación y adhesión por la Asamblea General de Naciones Unidas en su Resolución 39/46 del 10 de diciembre de 1984. Entrada en vigor: 26 de junio de 1987. < Disponible en http://www2.ohchr.org/spanih/ law/cat.htm $>$ [Consultado en fecha 23/11/2020].

ONU, Convención de Viena sobre el Derecho a los Tratados, U.N. Doc. A/CONF.39/27 (1969), 1155 U.N.T.S. 331, entró en vigencia en enero 27, 1980. Viena, 23 de mayo de 1969. < Disponible en https:/www.oas.org/xxxivga/spanish/reference_docs/convencion_ viena.pdf $>$ [Consultado en fecha 23/11/2020].

ONU, Declaración Universal de Derechos Humanos. Adoptada y proclamada por la Asamblea General de la ONU en Resolución 217 A (III), el 10 de diciembre de 1948 Artículo 5. Nadie será sometido a torturas o ni a penas o tratos crueles, inhumanos o degradantes. Disponible en:< http://www.un.org/es/documents /udhr/> [Consultado en fecha $23 / 11 / 2020]$.

ONU, Declaración sobre la Protección de Todas las personas contra la Tortura y Otros Tratos o Penas Crueles, Inhumanos o Degradantes, adoptada por la Asamblea General de Naciones Unidas en su Resolución 3452, del 9 de diciembre de 1975. Disponible en: $<$ http//dacces-dds-ny.un.org/doc/RESOLUTION/GEN/NRO/783/65/ PDF/NRO78365.pdf? OpenElement $>$ [Consultado en fecha 23/11/2020]. 
ONU, Informe del Comité de Expertos de Naciones Unidas contra la Tortura, (New York) 2020 disponible en< https://www.ohchr.org/ SP/HRBodies/cat/page/CATIndex.aspx> [Consultado 13/11/2020].

ONU, Pacto Internacional de Derechos Civiles y Políticos. Adoptado y abierto a la firma, ratificación y adhesión por Asamblea General en su resolución 2220 A (XXI) de 16 de diciembre de 1966 y entro en vigencia el 23 de marzo de 1976. Disponible en < http:// www2.ohchr.org/spanish/law/ccpr.htm $>$ [Consultado en fecha 23/02/2020].

ONU, Reglas mínimas de las Naciones Unidas para el tratamiento de los reclusos (Reglas Nelson Mándela) Ginebra, en 1955, y aprobadas por el Consejo Económico y Social en sus resoluciones 663C (XXIV) de 31 de julio de 1957 y 2076 (LXII) de 13 de mayo de 1977 disponible en<https://www.ohchr.org/sp/professionalinterest/pages/treatmentofprisoners.aspx $>$ [Consultado en fecha 23/02/2021].

Rivera BeIRAs, I., "La doctrina de las relaciones de sujeción especial en el ámbito penitenciario (la zona del "no derecho)", Legalidad constitucional y relaciones penitenciarias de especial sujeción, Bosch, Barcelona, (2000).

Vid Salado Osuna, A. Los Tortura y otros tratos prohibidos por el Convenio Europeo de Derechos Humanos, en García Roca, J Y Santolaya, P, La Europa de los Derechos: el Convenio Europeo de Derechos Humanos, $2^{\mathrm{a}}$ Ed, Madrid, (Centro de estudios políticos y constitucionales), 2009, p.107.-

ZafFaroni, R, la filosofía del sistema Penitenciario en el mundo contemporáneo ". Revista de derecho Penal Themis n. ${ }^{\circ}$ 35, Perú 1997, pp 179-191 disponible en < https://dialnet.unirioja.es/servlet/ articulo?codigo $=5109535>$.

\section{VII.1. Jurisprudencia de la Corte Interamericana de Derechos Humanos}

Cfr. Corte IDH. Caso Velázquez Rodríguez vs. Honduras. Sentencia de 29 de julio de 1988. Serie C no 4.-

Cfr. Corte IDH caso Loayza Tamayo vs. Perú, fondo, sentencia de 17 de septiembre de 1997. Serie C no 33.-

Cfr. Corte IDH caso Cantoral Benavides vs. Perú. Fondo. Sentencia de 18 de agosto de 2000 Serie C no 69.- 
Cfr. Corte IDH Caso Maritza Urrutia vs. Guatemala, fondo, reparaciones y costas, sentencia de 27 de noviembre de 2003. Serie $C$ no 103.-

Cfr. Corte IDH. Caso Los Hermanos Gómez Paquiyauri vs. Perú. Fondo, Reparaciones y Costas. Sentencia de 8 de julio de 2004, Serie C no 110.-

Cfr. Corte IDH caso Tibi vs. Ecuador, Sentencia del 7 de septiembre de 2004. Serie C no 114.-

Cfr. Corte IDH caso "Instituto de Reeducación del Menor" vs. Paraguay, excepciones preliminares, fondo, reparaciones y costas, sentencia de 2 de septiembre de 2004, Serie C no 112.-

Cfr. Corte IDH. Caso Caesar vs. Trinidad y Tobago, fondo, reparaciones y costas, sentencia de 11 de marzo de 2005. Serie C no 123.-

Cfr. Corte IDH caso Fermín Ramírez vs. Guatemala., fondo, reparaciones y costas, sentencia de 20 de junio de 2005. Serie C no 126.-

Cfr. Corte IDH. Caso del Penal Miguel Castro vs. Perú. Fondo, Reparaciones y Costas. Sentencia de 25 de noviembre de 2006. Serie C no 160.-

Cfr. Corte IDH Caso Montero Aranguren y otros (Retén de Catia) Vs. Venezuela. Excepción Preliminar, Fondo, Reparaciones y Costas. Sentencia de 5 de julio de 2006 Serie C no 150.-

Cfr. Corte IDH. Caso Bueno Alves Vs. Argentina. Fondo, Reparaciones y Costas. Sentencia de 11 de mayo de 2007. Serie C no 164.-

Cfr. Corte IDH Caso Bayarri Vs. Argentina. Excepción Preliminar, Fondo, Reparaciones y Costas. Sentencia de 30 de octubre de 2008. Serie C no 187.-

Cfr. Corte IDH caso Fernández Ortega y otro vs. México, excepción preliminar, fondo, reparaciones y costas, sentencia de 30 de agosto de 2010. Serie C no 215.-

Cfr. Corte IDH Caso Vera y otro Vs. Ecuador. Excepción Preliminar, Fondo, Reparaciones y Costas. Sentencia de 19 de mayo de 2011. Serie C no 226.-

Cfr. Corte Caso J. Vs. Perú. Excepción Preliminar, Fondo, Reparaciones y Costas. Sentencia de 27 de noviembre de 2013. Serie C no 275.-

Cfr. Corte IDH, caso Ximenes López vs. Brasil, 4 de julio de 2006. Serie $\mathrm{C}$ no 149.

Cfr. Corte IDH, caso Masacre de Rochela Vs. Colombia, fondo reparación y costas sentencia de fecha 11 de mayo de 2007. Serie C no 163.- 
Cfr. Corte IDH, Caso Cabrera García y Montiel Flores vs. México, fondo, reparaciones y costas, sentencia del 26 de noviembre de 2010 , Serie C No 220.-

Cfr. Corte IDH, Caso Fleury y otros vs. Haití, fondo, reparaciones, sentencia de fecha 23 de noviembre de 2011, Serie C No 236.-

Cfr. Corte IDH; caso Servellón García y otros Vs. Honduras, Sentencia del 21 de septiembre de 2006, Serie C No 152.-

Cfr. Corte IDH; Caso Goiburú y otros vs. Paraguay, fondo, reparaciones y costas, sentencia de 22 de septiembre de 2006, Serie C No. 153.-

Cfr. Corte IDH; Caso Lori Berenson Mejía vs. Perú, fondo, reparaciones y costa, Sentencia del 25 de noviembre de 2004, Serie C No 119.-

Cfr. Corte IDH; caso García Asto y Ramírez Rojas vs. Perú, Sentencia del 25 de noviembre de 2005. Serie C No 137.-

Cfr. Corte IDH; caso Baldeó García Vs. Perú, Sentencia del 6 de abril de 2006. Serie C No 147, párr. 117. 